\title{
Analysis of Site Suitability of Mosques Locations Using GIS: A Case Study of Khartoum State
}

\author{
Abdelrahim Elhag1, Ranya Fadlalla Elsheikh ${ }^{1,2}$, Faiza A. Yousif ${ }^{1}$ \\ ${ }^{1}$ Department of GIS, School of Survey, Faculty of Engineering, Sudan University of Science and Technology, Khartoum, Sudan \\ ${ }^{2}$ Department of Geographic and GIS, Faculty of Arts \& Humanities, Women Branches, King Abdulaziz University, Jeddah, \\ Saudi Arabia \\ Email: rasilna@hotmail.com,rfalsheikh@kau.edu.sa
}

How to cite this paper: Elhag, A., Elsheikh, R.F. and Yousif, F.A. (2017) Analysis of Site Suitability of Mosques Locations Using GIS: A Case Study of Khartoum State. Journal of Geoscience and Environment Protection, 5, $37-45$.

https://doi.org/10.4236/gep.2017.511004

Received: August 21, 2017

Accepted: November 5, 2017

Published: November 8, 2017

Copyright (ㅇ 2017 by authors and Scientific Research Publishing Inc. This work is licensed under the Creative Commons Attribution International License (CC BY 4.0).

http://creativecommons.org/licenses/by/4.0/

\begin{abstract}
The distribution of mosques needs to be assessed to help authorities to choose the appropriate location for the new mosques proposals, or to extend the existing mosques, the distribution and capacity of mosques is a serious problem in Islamic towns. This research aimed at finding appropriate planning standards, selection criteria for mosques locations and capacity by studying the current locations, distributions and capacities of the existing mosques. An aerial photograph was used as a source of spatial data. The distinctive orientation of the mosques to Gibla (Mecca holy mosque direction) facilitated their identification among other buildings. A layer of mosques was created in GIS. Each mosque area was calculated from the layer and saved in the attribute table. The actual capacity of each mosque (number of worshipers) was calculated by dividing the mosque area by 1 square meter. A buffer tool was applied, depending on the optimal distance for worshipers to access the mosques; the houses within the buffer area of each mosque were calculated to estimate the expected maximum number of worshipers for Friday prayer. The actual capacities of mosques were compared to the expected population. The results indicated that some mosques were found to be suitable; some needed to be extended within the existing location, while others could not be extended within the existing location and a new location must be determined for a new mosque within the buffer area to accommodate the expected number of worshipers.
\end{abstract}

\section{Keywords}

GIS, Mosques, Site Suitability, Planning Standards, Khartoum 


\section{Introduction}

Choice of mosques locations together with the appropriate capacity sufficient for the number of worshipers is a serious problem in Islamic towns, added to nonobservance of planning standards in the areas of mosques to cope with population growth and urban expansion. Site selection is a very important activity aimed at producing optimal mosques locations. Site selection for mosques involved combining large amounts of statistics, written narrative, questionnaires as well as some sample geographic methods. Probably the typical geographic was using Tisane polygon. Voronoi diagram is a process of decomposing a specific space in the basic distances of object. These objects are usually called sites. The principle of this diagram is to produce regions whose boundaries define the area in which the distance of any location to any given site is not greater than the distance to the other sites [1]. The purpose of the optimum site selection is to find the optimal location based on predefined criteria [2] [3] [4] [5] [6].

This research aims to find appropriate planning standards to solve this problem by studying the existing location, distribution, and capacity of the existing mosques, using Geographic Information System (GIS). GIS can enhance the accessibility and flexibility of information and improve the linkages and the understanding of relationship between different types of information [7]. The system can treat the spatial data (maps, aerial photos... etc.) and descriptive data (names, tables), and revision of the error, storage, retrieval, inquiry, spatial and statistical analysis, and display data on a computer screen or on paper in the form of maps, reports, charts, graphic or through the website [8]. The use of GIS and multi criteria analysis has helped planners to achieve desired and more accurate results [1]. GIS is used today in several planning applications including land use, health care, and transportation [9].

The distribution of mosques in residential areas must take into consideration their distance from each other and the number of mosques must be compatible with the number of houses around them. In previous studies, some hypotheses were introduced as the following example. In narration mosque should be built to cover forty houses in each direction. According to this narrative, for every 160 homes people could be built a mosque in the center [10].

\section{Location of Mosque}

The location and chosen mosque location and its relation to the other elements of the urban area to the main themes in the history of Muslim cities. Sometimes it was determined that the construction of the neighborhood or towns, the location of the mosque and then founded the establishment of urban spaces. The first example, the mosque of the Prophet in Medina is that its location was determined by divine inspiration [10]. The location of the mosques depend on multi criteria: Criteria are variables that justify or explain the environmental impact on making decision to select the most suitable site for a project. They are chosen depending on the characteristics of the alternative. It is necessary to have enough information about the chosen criteria to allow for comparison among 
the alternative [11].

The planner should take into account some of the major planning considerations that raise a mosque and strengthen it in the hearts of Muslims. The researchers summarize the most important considerations for mosque planning according to [12].

1) The mosque's location should be away from noise, pollution, smoke and other environmental hazards.

2) Mosque site must be integrated with the built environment and urban fabric, and preferably in the center of public services.

3) The site must be found in a permissible location in Sharia, cannot be in graves, unclean, occupied, or public used land.

4) The selected land to establish a new mosque must not be adjacent to another mosque, which cause a dispersion of Muslims

5) The mosque location must be supported by good roads and pedestrian paths with possible shades and trees.

6) The exploitation of the mosque as an attraction point based on the visual aspect, and the minaret as a distinctive sign [8].

7) The location of the mosque must avoid high noise; activities such as industrial development project and traffic [13].

Many factors affect the choice of mosque locations. Some do not cope with planning criteria, and may be according to particular beliefs. Location of a mosque is a divine affair because "Divine guidance is for the houses which Allah has given permission to be raised and praised and the name of Allah is remembered in purity morning and nights and the mosque can be raised and built with grandeur only where God allows [14]".

The choice of mosque location must consider optimal distance for worshipers to access the mosques, and should not be built in the areas far from houses. Accessibility is the ease of entry to and exit from a particular site in a residential area. The variables that should be considered when measuring accessibility include the number of traffic lanes, traffic speed and congestion, and traffic control devices [15]. Physical accessibility is a measure of the capacity of a location to be reached by, or to reach different location [16].

In this paper some mosques are built inside companies and inaccessible to worshipers outside this company to pray, and also the companies do not have the available space to extend the mosque for their labors. Extension of mosques using temporary material such as zinc is not a good solution. Some mosques are very close to each other according to the existence of different doctrines, regardless of the need of the population. Mosques names can be according to the doctrine's name, name of districts, name of donors, or name of one of the Prophet's first followers (Sahabi).

\section{Materials and Methods}

\subsection{Study Area}

The position of the study area in Khartoum state located between blue Nile, white 
Nile and Khartoum-Gezira expressway, located between Easting [446182.92E and $457691.42 \mathrm{E}$ ] and Northing [ $172555.22 \mathrm{~N}$ and $1718022.86 \mathrm{~N}$ ], the study area is 82241673 square meters approximately (Figure 1).

An aerial photograph was used to facilitate the Identification of mosques among other buildings by distinctive orientation of them to Gable (Figure 2).

\subsection{Research Method}

Arc GIS 10.3 was used to determine the location of the mosques in the aerial Photograph and in the map as indicated in Figure 3 and Figure 4.


scale: $1: 100000$

Figure 1. Study area in map of Khartoum state.

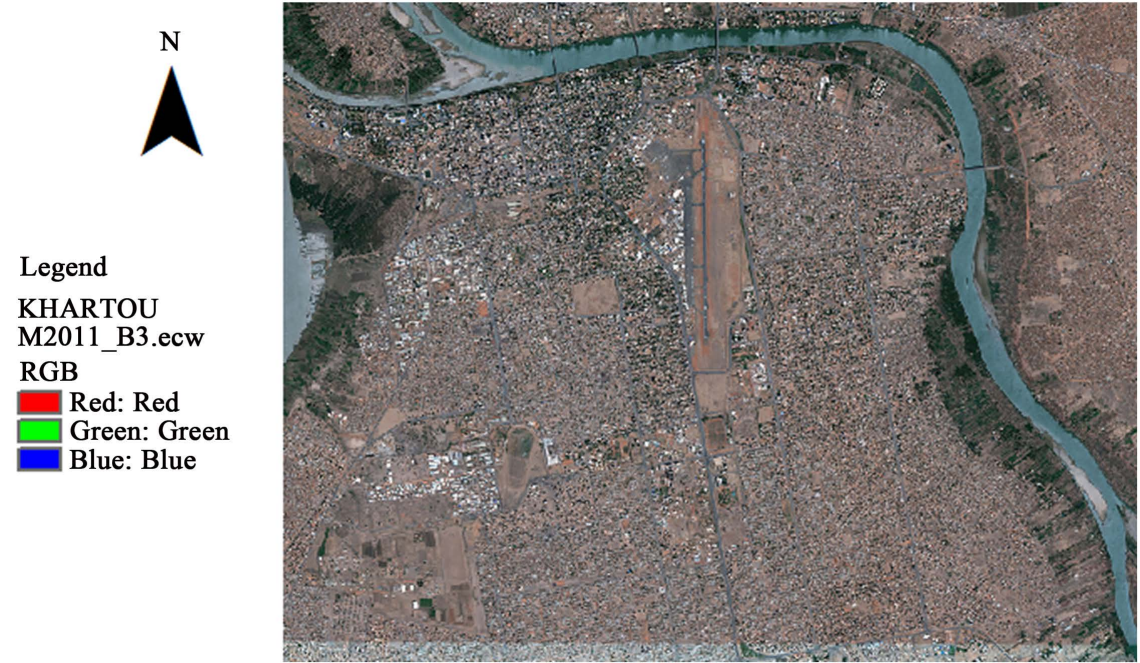

Figure 2. An aerial photograph of the study area. 


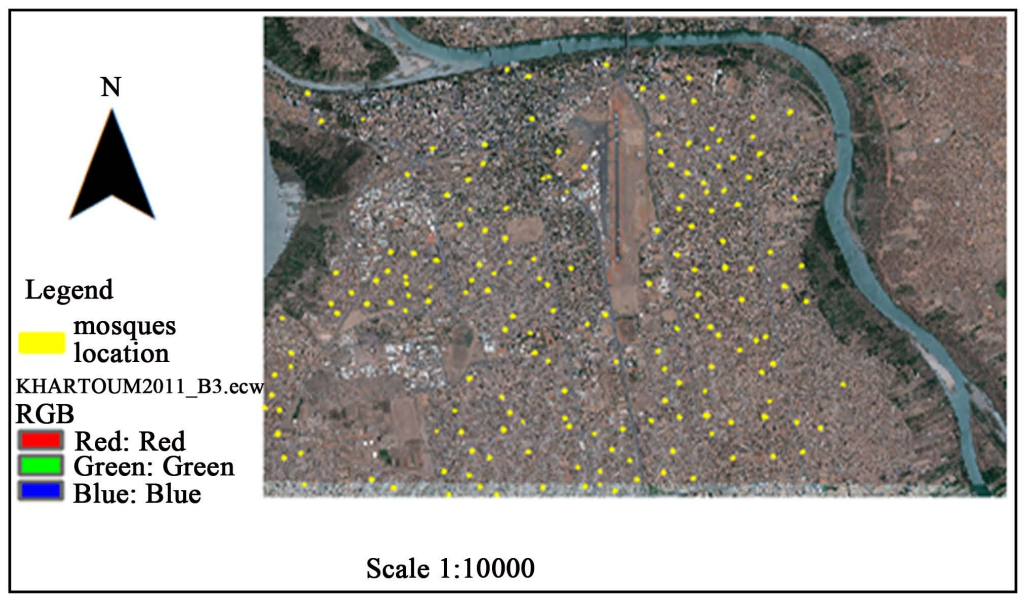

Figure 3. Location of mosques in aerial photograph.

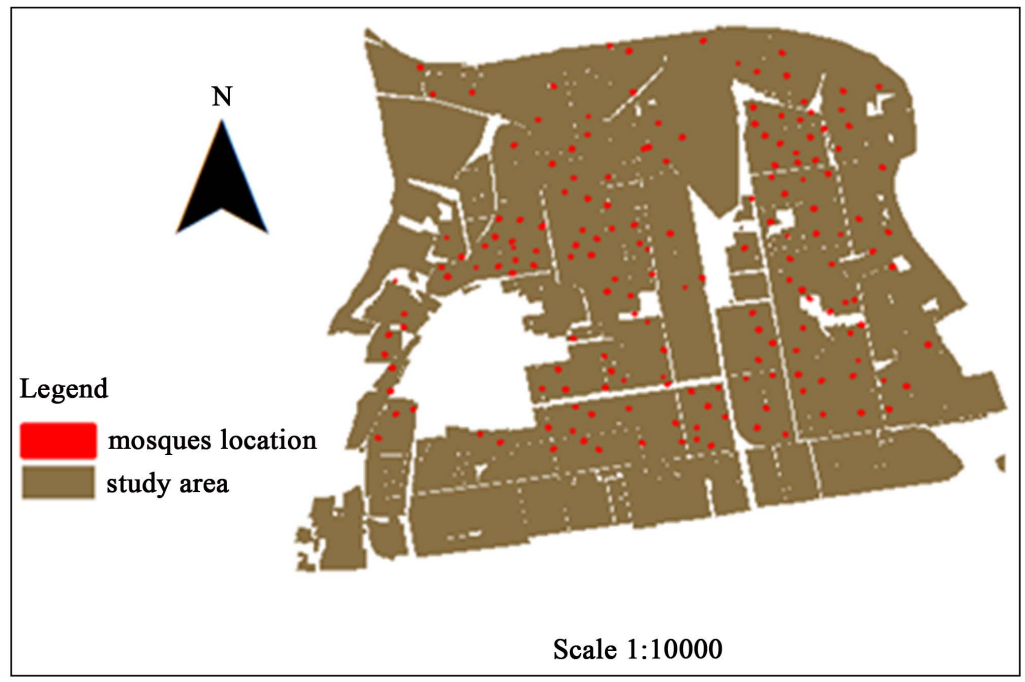

Figure 4. Map of the location of the mosques.

The mosques had been added to the map and total area of mosques had been calculated, together with the main built up area, extended buildings areas and empty spaces. Calculated areas were recorded in the attribute tables in Table 1. Attribute table includes information such as id number for mosque, mosque name, interior areas, total areas, extra areas of any mosque, locality of the mosque, district of the mosque, material of extra areas, wc, worshiper number, needed areas to expand.

A buffer tool of 300 meters around any mosque had been applied, depending on the optimal distance for worshipers to access the mosque within 10 minutes by walking speed of 2 kilometer per hour (Figure 5). It is assumed that $10 \mathrm{mi}-$ nutes is the sufficient time for the worshiper to reach the mosque after prayer call time (Azan) and prayer starting time.

The buffer area had been used to clip the area around each mosque. The following criterions were designed to extract the number of worshipers based on the expert's opinion from the Ministry of Planning: 
Table 1. Attributes of mosques.

\begin{tabular}{|c|c|c|c|c|c|c|c|c|}
\hline FID & area & mosque_nam & district & total_area & extra_area & material & $w_{-} c c$ & worshipers \\
\hline 0 & 386 & burri allamab mosque & burri allamab & 2859 & 46 & zincs & yes & 430 \\
\hline 1 & 589 & omak street mosque & al riyadh & 2997 & 107 & zincs & yes & 362 \\
\hline 2 & 314 & al taif mosque & al taif & 1635 & 534 & zincs & yes & 378 \\
\hline 3 & 419 & alferdawes mosque & alferdawes & 2398 & 0 & & yes & 560 \\
\hline 4 & 385 & alemarat collage mosque & aljeraif west al sheta & 2432 & 68 & zincs & yes & 6066 \\
\hline 5 & 412 & Martyr Haj Nour Mosque & al mamora & 2763 & 393 & zincs & yes & 400 \\
\hline 6 & 434 & street no 33 mosque & aljeraif west al sheta & 2747 & 139 & bricks & yes & 352 \\
\hline 7 & 365 & burri allamab mosque & burri allamab & 1607 & 102 & zincs & yes & 760 \\
\hline 8 & 400 & alharaa altaltaa mosque & aljeraif west al galaa & 2712 & 183 & zincs & yes & 126 \\
\hline 9 & 427 & aljeraif west al sheta mosque & aljeraif west al sheta & 3039 & 0 & & yes & 326 \\
\hline 10 & 468 & dawhat al eman mosque & aljeraif west al galaa & 1880 & 0 & & yes & 274 \\
\hline 11 & 549 & almamoraa mosque & almamoraa & 3728 & 152 & zincs & yes & 532 \\
\hline 12 & 305 & block 63 mosque & block 63 & 1414 & 0 & & yes & 654 \\
\hline 13 & 625 & arkaweet mosque & arkaweet & 4460 & 0 & & yes & 570 \\
\hline 14 & 386 & alferdawes north mosque & alferdawes north & 2098 & 0 & & yes & 734 \\
\hline 15 & 521 & alferdawes north mosque & alferdawes north & 3585 & 0 & & no & 578 \\
\hline 16 & 474 & al nakheel street mosque & arkaweet & 1551 & 0 & & yes & 722 \\
\hline 17 & 353 & Rayyan Mosque & arkaweet & 1298 & 0 & & yes & 730 \\
\hline 18 & 274 & badar st mosque & al riyadh & 647 & 0 & & no & 618 \\
\hline 19 & 542 & al salam mosque & al taife & 3814 & 0 & & yes & 488 \\
\hline 20 & 340 & gis office road mosqe & al taife & 2212 & 0 & & yes & 572 \\
\hline
\end{tabular}

Legend
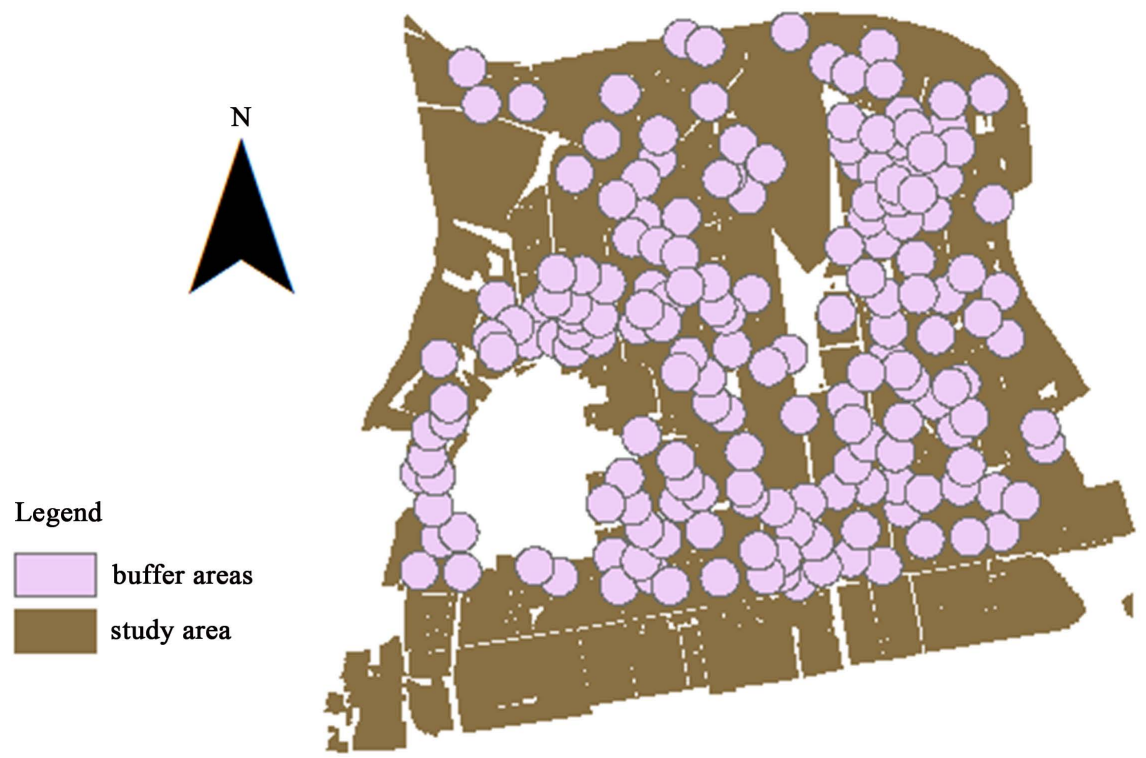

Figure 5. Map of the buffer around mosques.

1) Assume an area of each worshiper at the mosque is equal to 1 square meter.

2) Assume the number of worshipers is equal to 2 in every house.

3) Expected worshiper number in the buffer area around the mosque $=$ number of houses in the buffer area multiplied by 2 . 
4) Actual capacity of the mosque is equal to mosque built area divided by 1 square meters $(1.25 \times 0.83)$.

To assess the suitability of each mosque a comparison between expected number of worshipers and actual capacity of the mosque was conducted; if the expected number of worshipers is less than the actual capacity of the mosque, then this mosque is sufficient for worshipers; if the expected number of worshipers is greater than the actual capacity of the mosque then this mosque need to be extended within the existing location; if it is feasible otherwise a new location must be selected to accommodate the excess number of worshipers.

\section{Result and Discussion}

Applying GIS in the analysis of mosques locations and capacity indicated that some mosques are suitable, some need to be extended within the existing location, some cannot be extended within the existing location and selection of new location is needed to accommodate the excess number of worshipers

Mosques were classified a corroding to their capacity and the classification map was produced (Figure 6).

1) Mosques shown by yellow color have sufficient space for worshipers.

2) Mosques shown by light green color include extensions outside the main building.

3) Mosques shown by red color do not have sufficient capacity and can be extended within the existing location.

4) Mosques shown by solid green color do not have sufficient space for worshipers and cannot be extended, so new mosques are suggested within the area.

The result found that $22 \%$ of mosques have sufficient capacity for worshipers while, $50 \%$ need to be extend in the existing location. On the other hand $16 \%$ have sufficient space if the outdoor area were considered. By contrast, $12 \%$ of mosques do not have sufficient capacity and cannot be extending (see Figure 7).

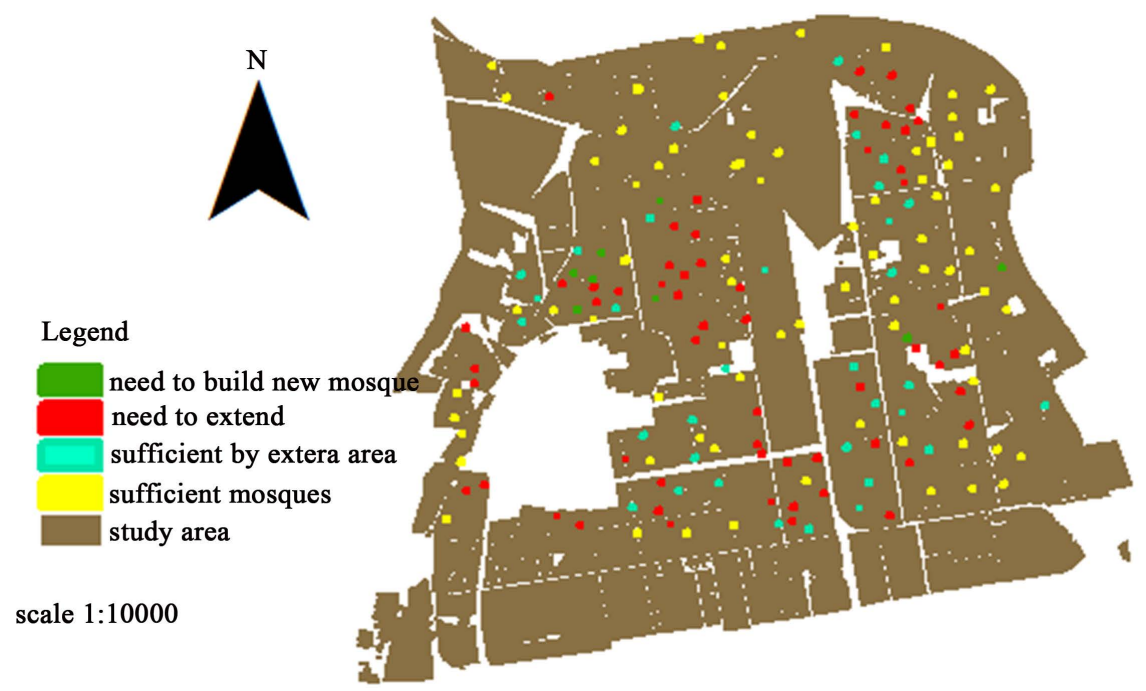

Figure 6. Map of the mosques classification according to their capacity. 


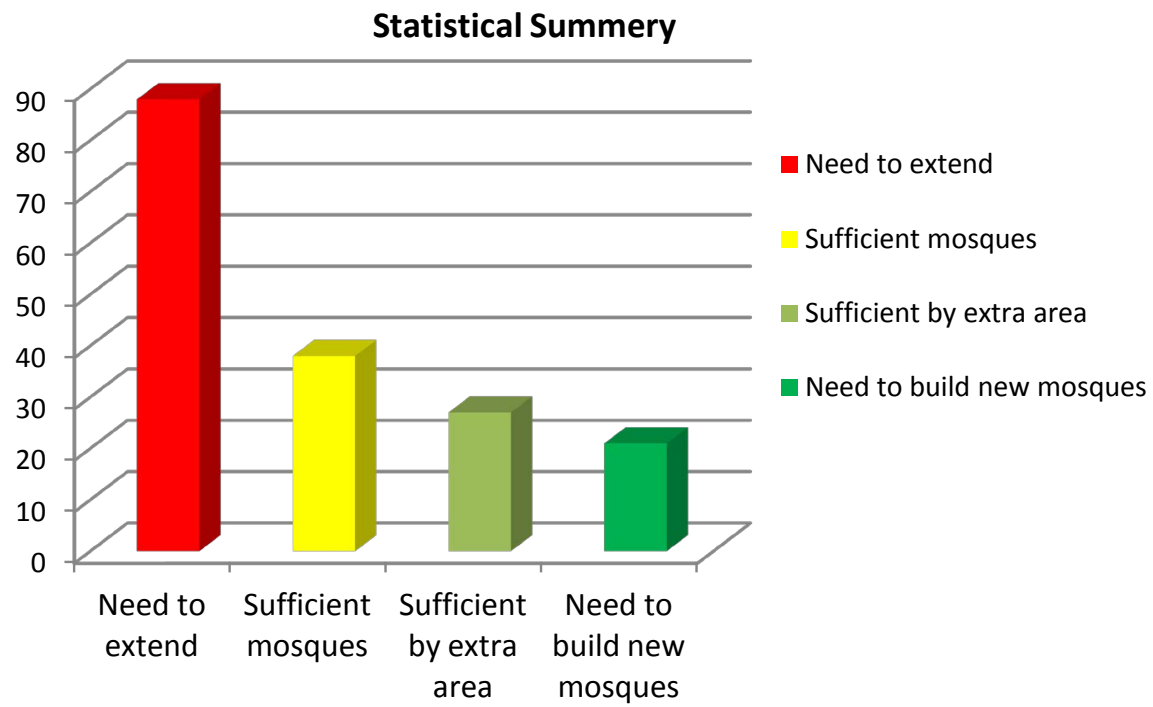

Figure 7. Statistical summary.

\section{Conclusion}

Analysis of results for the location, distribution, and capacity of the existing mosques, had shown that: some mosques have met all conditions, some need to be extended within the existing location, some are not capable for extension within the existing location and new location must be selected to cope with actual number of worshipers, and it is highly recommended to design mosques as multi stories for vertical extension.

\section{References}

[1] Ahmed, N.G. and Asmael, N.M. (2009) A GIS-Assisted Optimal Urban Route Selection Based on Multi Criteria Approach. The Iraqi Journal for Mechanical and Material Engineering, 2, 557-567.

[2] Chehreghan, A., Rajabi, M. and Pazoki, S.H. (2013) Developing a Novel Method for Optimum Site Selection Based on Fuzzy Genetic System and GIS. International Journal, 3, 165.

[3] Malczewski, J. (1999) GIS and Multicriteria Decision Analysis. Wiley and Sons INC, 395.

[4] Ghamgosar, M., et al. (2011) Multicriteria Decision Making Based on Analytical Hierarchy Process (AHP) in GIS for Tourism. Middle-East Journal of Scientific Research, 10, 501-507.

[5] Elsheikh, R.F.A., Shariff, A.R.B.M. and Patel, N. (2015) Mango Suitability Evaluation Based on GIS, Multi Criteria Weights and Sensitivity Analysis. International Journal of Advanced Computer Research, 5, 25.

[6] Elsheikh, R.F.A. (2017) Multi-Criteria Decision Making in Hotel Site Selection. International Journal of Engineering Science Invention, 6, 15-18.

[7] Baniya, N. (2008) Land Suitability Evaluation Using GIS for Vegetable Crops in Kathmandu Vally/Nepal. University of Berlin, Berlin.

[8] El Jamassi, A., Al-Qeeq, F. and Shehada, Z. (2013) Pattern Analysis of Mosques in Gaza-Palestine by Using GIS (Geographic Information Systems). An-Najah Univ. J. Res. (N. Sc.) Vol. 27, Islamic University, Gaza, 30-52. 
[9] Al-Enazi, M., Mesbah, S. and Anwar, A. (2016) School Distribution Planning Using GIS in Jeddah City. International Journal in Computer Applications, 138, 33.

[10] Abadi, Z.K., Najarzdeh, M. and Masoudi, S. (2015) Evaluating the Structural of the Mosque Position in Islamic Cities (Using Software GIS) Region 5 Tehran Sample Case. Text Road Publication, Department of Geography, Collage of Human Science, Semnan Branch, Islamic Azad University, Semnan, 411-416.

[11] Jalaliyoon, N., Arastoo, A. and Pirouti, A. (2015) Land Selection: Using Multiple Criteria Decision Making. International Journal of Academic Research in Management (IJARM), 4, 14-23.

[12] Ibrahim, H. (1979) Planning Criteria of Mosques. Ministry of Municipal and Rural Affairs. First Issue. Saudi Arabia.

[13] Bukhari, Z., Rodzi A.M. and Noordin, A. (2010) Spatial Multi-Criteria Decision Analysis for Safe School Site Selection. International Geoinformatics Research and Development Journal, 1, 1-14.

[14] Ghorbannejad, P. (2014) Location Pattern of Mosques: The Case Study of Nabi Mosque According to Verses, Hadithes and Prophet's Sira. International Journal of Culture and History, 1, 15. https://doi.org/10.5296/ijch.v1i2.5971

[15] Hj. Mar Iman, A.H., bt. Isail, S. and bt. Martin, R. (2009) Site Potentiality of Petrol Station Based on Traffic Counts. Malaysian Journal of Real Estate, 4, 13.

[16] Naghawi, H. (2012) Using Geographic Information System in Analyzing Hospital Accessibility: A Case Study in New Orleans, Jordan Journal of Civil Engineering, 6, 353. 